Univerzitet u Beogradu
Poljoprivredni fakultet
Institut za poljoprivrednu tehniku
Naučni časopis
POLJOPRIVREDNA TEHNIKA
Godina XLIII
Broj 3, 2018.
Strane: $1-10$

\title{
OZONE PENETRATION IN A COLUMN CONTAINING SUNN HEMP (Crotalaria spectabilis Roth) SEEDS AND THE EFFECT ON THE QUALITY
}

\author{
Suian José Granella ${ }^{* 1}$, Taise Raquel Bechlin ${ }^{1}$, Ivan Werncke ${ }^{1}$, Divair Christ ${ }^{1}$ \\ ${ }^{1}$ Western Parana State University, Exact Sciences \& Technology Center, \\ Pgeagri, Cascavel-PR, Brasil
}

\begin{abstract}
Ozone owns high oxidative potential against a broad microbial spectrum and can be applied directly in grain and seed for decontamination fungal and mycotoxin reduction. Thus, the objective of this work was to evaluate the effect of ozonation in the control of fungi and on sunn hemp seeds quality. For this, a cylindrical column of $15 \mathrm{~cm}$ diameter PVC was used for ozonation at different heights of the seed layer 2.95 to 17.05 $\mathrm{cm}$ and in different times of exposure ozone $(17.7,30,60,90$ and $102.3 \mathrm{~min}$ ) according to central composite rotatable design (CCRD). It was evaluated the effect of ozone on decontamination by fungi, moisture content and electric conductivity of sunn hemp seeds. Results of CCRD show different reductions of fungi and a second-order linear model was proposed (average absolute deviation $7.79 \%$ and $\mathrm{R}^{2}=0.67$ ). Fungi reduction $(92.37 \%)$ was significantly higher in lower layers of the seed column and in longer ozone exposure times, values corresponding to $10 \mathrm{~cm}$ and $102.7 \mathrm{~min}$, respectively. Results also showed that ozonation did not influence significantly electrical conductivity and moisture content of seeds $(p$-value $<0.05)$. Thus, application of ozone can ensure maintenance of sunn hemp seeds in post-harvest without damaging your quality.
\end{abstract}

Key words: Ozonation, Crotalaria spectabilis Roth, fungi, post-harvest quality

\footnotetext{
${ }^{*}$ Corresponding author. E-mail: suian.granella@unioeste.br Acknowledgements: The authors would like to thank CAPES (Coordination for the Improvement of Higher Education Personnel of Brazilian government) for supporting part of this research.
} 


\section{INTRODUCTION}

Crotalaria spp. is a legume used as a cover for weed control and for the supply of organic matter to the soil and therefore is used to increase nitrogen content through your symbiosis with Rhizobium [1]. Species such as Crotalaria spectabilis Roth are attractive or repellent semi-chemical plants known as "push-pull" [2,3]. Crotalaria juncea L. was promising to compose the intercropping with the maize crop in some regions of Brazil [4]. The use of a consortium can bring benefits such as optimization of planting area, nitrogen fixation, soil cover and nitrogen availability.

An understanding of factors that determine the quality of seeds is important in the maintaining efficient and sustainable agricultural production. The maintenance of grain quality is determined by the genetic potential of variety and environment in which it is produced. The quality also depends on postharvest handling and storage of grain. However, quality is delimited for each species, is important, yet, consumer preferences and success of a product on market.

A high quality of the product is important, to avoid development of microorganisms and fungi and contamination with toxins for him during storage and transport. Thus, the study of new physical, thermal and biochemical processes becomes essential to prevent problems associated with grains and seeds postharvest, ensure high product quality and reduce losses.

One of these methods is ozonation, application of ozone gas $\left(\mathrm{O}_{3}\right)$, a microbial oxidation method that can be applied directly in agricultural products. And have been an effective agent of fungal and mycotoxin control inactivity associated with agricultural products [5-8].

However, ozone penetration is inversely proportional to the time of seed layer and adsorption depends on your ozone concentration, duration of exposure, gas flow, temperature, grain characteristics and the presence of organic materials, such as insects and microbial surface status of grain [9].

However, according to previous reports $[10,11]$ ozone can still influence the qualitative properties of agricultural products, causing color loss, development of undesirable aromas, alteration of sensory and nutritional quality of the product and thus able to influence in the vigor of seed. In this context, ozonation can be an alternative for controlling and improving grains and seeds quality, the aim of this study to evaluate different conditions of ozonation and column height of sunn hemp seed under reduction levels fungi and physiological quality (moisture content and electrical conductivity).

\section{MATERIAL AND METHODS}

Sunn hemp seeds (Crotalaria spectabilis Roth), $14.5 \%$ d.b. original moisture content, were produced in Medianeira-PR, Brazil. This crop was manually picked to remove the broken and immature grains. The seeds samples were stored in plastic bags at approximately $5{ }^{\circ} \mathrm{C}$. The experiment started in $2^{\text {nd }}$ semester 2017 at the Laboratory of Storage and Prototyping of Drying Installations and the Laboratory of Control and Quality of Agricultural Products, both at the Western State Paraná University (UNIOESTE), Campus of Cascavel.

A generator with a capacity of $2.0 \mathrm{~g}\left(\mathrm{O}_{3}\right) \mathrm{h}^{-1}$ was used for ozone production, using the environment air as input for the production, which is based on corona discharge. 
The $\left(\mathrm{O}_{3}\right)$ gas was injected in the experimental silo made of PVC cylinder $(0.45 \mathrm{x}$ $0.15 \mathrm{~m}$, length $\mathrm{x}$ diameter) filled with sunn hemp seeds, which were suspended $20 \mathrm{~cm}$ of the base by PVC mesh (Fig. 1). The $\left(\mathrm{O}_{3}\right)$ was injected different times and heights of the seed layer according to the experimental design. The air velocity was measured at the start of all drying and ozonation treatments, with a value of 0.38 to $0.5 \mathrm{~m} \mathrm{~s}^{-1}$.

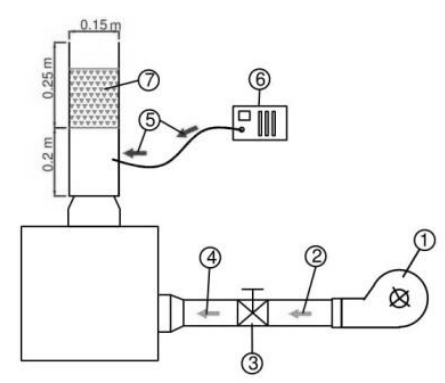

Figure 1. Schematic diagram showing the ozonation process: 1. Centrifugal ventilator; 2, 4. Cool airflow; 3. Valve; 5. Ozone gas flow; 6. Ozone generator; 7. Seeds column

Central composite rotational design (CCRD) with two factors, exposure to ozone (X1) and seed column height (X2), was considered for statistical analysis. Each factor in the experiment was established and encoded in five levels, two axial $(-1.44$ and +1.44$)$, low (-1), medium (0) and high (+1), X1 values of 17.7, 30, 60, 90 and $102.7 \mathrm{~min}$, and X2 of $2.95,5,10,15$ and $17.05 \mathrm{~cm}$. Totalizing 11 treatments (Tab. 1). These values were used, because, according to pre-work done with this ozonation process on other seeds, such as wheat, maize, and soybean, it was the best initial results obtained.

Table 1. The matrix of central composite rotation design with the real and coded values

\begin{tabular}{|c|c|c|c|c|}
\hline \multirow{3}{*}{ Runs } & \multicolumn{2}{|c|}{ Coded values } & \multicolumn{3}{c|}{ Real values } \\
\cline { 2 - 5 } & $X_{1}$ & $X_{2}$ & $\begin{array}{c}\text { Ozonation time (min) } \\
X_{1}\end{array}$ & $\begin{array}{c}\text { Column height (cm) } \\
X_{2}\end{array}$ \\
\hline 1 & -1 & -1 & 30 & 5 \\
\hline 2 & 1 & -1 & 90 & 5 \\
\hline 3 & -1 & 1 & 30 & 15 \\
\hline 4 & 1 & 1 & 90 & 15 \\
\hline 5 & -1.44 & 0 & 17.7 & 10 \\
\hline 6 & 1.44 & 0 & 102.3 & 10 \\
\hline 7 & 0 & -1.44 & 60 & 2.95 \\
\hline 8 & 0 & 1.44 & 60 & 17.05 \\
\hline 9 & 0 & 0 & 60 & 10 \\
\hline 10 & 0 & 0 & 60 & 10 \\
\hline 11 & 0 & 0 & 60 & 10 \\
\hline
\end{tabular}


Fungal count total, electric conductivity and moisture content were selected as dependent variables of the process. The results were analyzed according to a significance test and analysis of variance (ANOVA) to assess the fit quality of model shown below:

$$
\mathrm{Y}=\mathrm{b}_{0} \quad \mathrm{~b} \quad \mathrm{~b} \quad \mathrm{~b}
$$

where is: $\mathrm{Y}$ is a response, $\mathrm{b} 0$ is intercept term, $\mathrm{b} 1-\mathrm{b} 2$ are coefficients of linear terms, b12 is the coefficient of the interaction term, $\mathrm{X} 1$ and $\mathrm{X} 2$ are factors.

The effectiveness of RSM prediction capability was assessed by comparison of the predicted responses and experimental responses. The absolute average deviation (AAD) and coefficient of determination (R2) were determined for the model and the model accuracy was established by calculating these parameters. Eq. (2) was used for computing ADD:

$$
\text { A }(\%)=\left(\frac{-}{n} \sum_{i=}^{n}\left|\frac{y_{i, o b s} y_{i, \text { st }}}{y_{i, o b s}}\right|\right) \text { x } 00
$$

where is: yi,obs is the observed values and yi,est is the estimated values for the model.

To evaluate the reducing effects of ozonation on fungal decontamination, dried and ozonized samples of wheat seeds were analyzed according to official procedures of enumeration of total fungi in foods. The samples of seeds, containing $25 \mathrm{~g}$ each, were transferred to $500 \mathrm{~mL}$ Erlenmeyer flasks and then $225 \mathrm{~mL}$ of $0.1 \%$ peptone salt solution was added. Samples were then homogenized for $60 \mathrm{~s}$ in dilution $10^{-1}$. From this, dilutions $10^{-2}$ and $10^{-3}$ were made up using tubes containing $9 \mathrm{~mL}$ of $0.1 \%$ peptone salt solution. Surface plating was carried out on DRBC agar, with $0.1 \mathrm{~mL}$ of inoculum. Plates were incubated at $5^{\circ} \mathrm{C}$ for 5 days in a B.O. . incubator. After this period, total colonies were counted and the results were expressed in cfu $\mathrm{g}^{-1}$ of sunn hemp seeds [12].

For identification of the genus level of colonies of isolated filamentous fungi, a microscopic observation of their morphological structures was made in accordance with the method described in [13].

The electrical conductivity test was conducted through the center-of-mass system with four replicates of 50 seeds per treatment. The seeds were accurately weighed to two decimal places after the decimal point, and then placed in $200 \mathrm{~mL}$ can fill with $75 \mathrm{~mL}$ deionized water, and kept in B.O. . at a constant temperature of $5^{\circ} \mathrm{C}$. After 4 hours of soaking, electrical conductivity was measured in the soaking solution, by using a digital conductivity meter. The results were expressed in $\mu \mathrm{S} \mathrm{cm}^{-1} \mathrm{~g}^{-1}$ [14].

Moisture content determined by the oven gravimetric method at $05{ }^{\circ} \mathrm{C}$, for 4 hours, using three subsamples of $25.0 \mathrm{~g}$ of seeds for each repetition [15]. The values were expressed on a dry basis percentage $(\%, \mathrm{~d} . \mathrm{b}$.).

\section{RESULTS AND DISCUSSION}

Control samples of sunn hemp seeds showed the following values to fungal count total, electrical conductivity and moisture content, respectively, of $98.33 \mathrm{ufc} \mathrm{g}^{-1}, 146.31$ $\mu \mathrm{S} \mathrm{cm} \mathrm{cm}^{-1}$ and $14.5 \%$ (d.b.). Fungi of the genera Fusarium, Aspergillus, and Penicillium were identified in seeds samples and different values of fungal count reductions were found among the treatments evaluated. 
The values shown in Table 2 were used in CCRD, where it has been possible to study effects of each independent variable selected, as well as their interactions under total fungi, count levels, conductivity electrical of exudates and moisture content after the ozonation process.

Table 2. Electrical conductivity (EC) $\mu S \mathrm{~cm}^{-1} \mathrm{~g}^{-1}$; moisture content (MC) \% d.b.; and reduction of fungi $(R F) \%$ values for the ozonation process of sunn hemp seeds according to each run.

\begin{tabular}{|c|c|c|r|r|r|}
\hline Runs & $\begin{array}{c}\text { Ozonation time } \\
(\mathrm{min})\end{array}$ & $\begin{array}{c}\text { Column height } \\
(\mathrm{cm})\end{array}$ & $\begin{array}{c}E C \\
\left(\mu \mathrm{cm}^{-1} \mathrm{~g}^{-1}\right)\end{array}$ & $\begin{array}{c}M C \\
(\% \mathrm{~d} . \mathrm{b})\end{array}$ & $\begin{array}{c}\text { RF } \\
(\%)\end{array}$ \\
\hline 1 & 30 & 5 & 167.48 & 10.91 & 58.05 \\
\hline 2 & 90 & 5 & 155.31 & 10.69 & 66.14 \\
\hline 3 & 30 & 15 & 173.36 & 12.94 & 58.69 \\
\hline 4 & 90 & 15 & 160.32 & 11.58 & 79.03 \\
\hline 5 & 17.7 & 10 & 176.65 & 13.11 & 53.80 \\
\hline 6 & 102.3 & 10 & 178.65 & 10.74 & 92.37 \\
\hline 7 & 60 & 2.95 & 208.82 & 10.74 & 74.58 \\
\hline 8 & 60 & 17.05 & 155.46 & 10.51 & 52.30 \\
\hline 9 & 60 & 10 & 156.57 & 12.35 & 64.41 \\
\hline 10 & 60 & 10 & 153.09 & 11.67 & 65.04 \\
\hline 11 & 60 & 10 & 157.89 & 11.81 & 65.68 \\
\hline
\end{tabular}

Figure 2 represents the Pareto chart that shows the terms considered by Student's ttest analysis. To response variable electrical conductivity (EC) only column height factor had influence $(\mathrm{p}<0.05)$, being this negative influence, i.e., the values EC were greater significantly in lower layers of seeds. Moisture content (MC) during the process was influenced only by exposure to ozone, being this negative influence, thus lower moisture contents were reached when higher ozonation time was applied. However, none model was established because only one of the factors was significant for each variable response (EC and $\mathrm{MC}$ ), according to variance analysis (Fig. 2A and 2B).
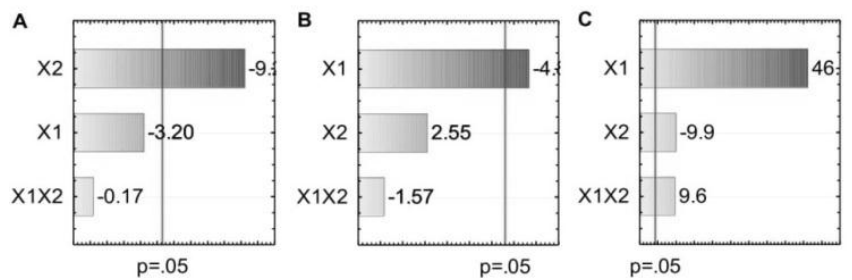

Figure 2. Pareto chart showing the terms considered by the t-test of the factors:

A. electrical conductivity $\left(\mu S \mathrm{~cm}^{-1} \mathrm{~g}^{-1}\right), \quad B$. moisture content $(\%$ d.b) and C. reduction of count fungus (\%) for ozonation process of sunn hemp seeds. 
The ozone exposure time had the greatest influence in reducing the levels of the fungal count in sunn hemp seeds with positive influence, already the column height had a negative influence (Fig. 2C), i.e., it was inversely proportional with the increase of fungi reduction.

The results of the ANOVA and significance test of regression equation model are presented in Table 3C for fungal reduction of the sunn hemp seed after ozonation. The effect of the factors was considered statistically significant at $95 \%$ confidence level $(p<0.05)$. The F-value of 4.79 in comparison with the tabled $F$ value of 4.35 , showed that the developed mathematical models of the second order were statistically significant at $95 \%$ of confidence level $(\mathrm{p}<0.05)$, level of fungal decontamination on sunn hemp seeds is in function at ozonation time (X1) and height column (X2). The fitted model is presented in sequence:

$$
=66.7 \quad 0 . \quad .4 \quad .06
$$

The model had an AA value $7.79 \%$ and $\mathrm{R}^{2} 0.67$ indicating a high level of accuracy of the model prediction.

Figure 3 follows the graphical representation of the estimated values in relation to the observed values for reduction of the fungal count. According to Figure 3, the lower reduction in the count of fungi was using the smallest $\mathrm{O}_{3}$ exposure times and top heights of the seed layer, these conditions are equivalent to 102.3 mim of ozonation time and 10 $\mathrm{cm}$ of column height.

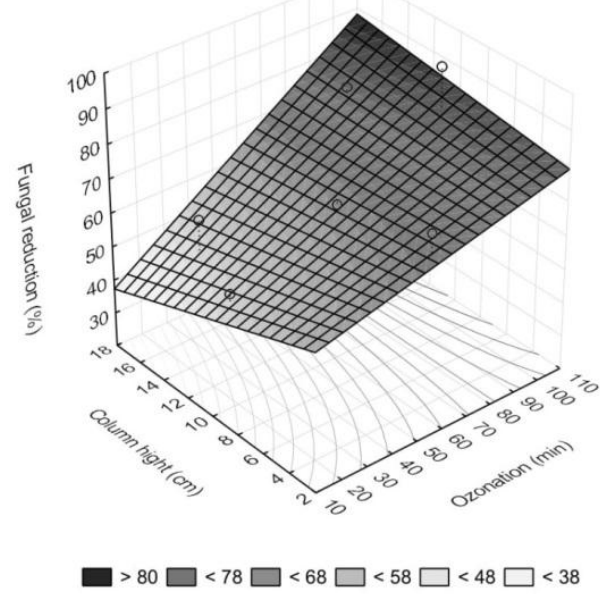

Chart 3. Response surface on reduction of count fungus to ozonized sunn hemp seeds.

The ability to control of fungal species, as those found in this study, confirms the efficiency that ozone has against a number of micro-organisms without damaging to quality of agricultural products, it has been reported for others researcher [16-20]. Ozone can also be applied in the various stages of agricultural production for your ease of handling and without generating waste, but it is most used in the post-harvest phase, mostly in storage in pest control and reducing chemical contaminants [21-25], other studies report the use of ozone to improve the drying process of grains and seeds [26, 27]. 
Thus, results obtained in this work can be compared to Trombete et al. (2017) using $60 \mathrm{mg}\left(\mathrm{O}_{3}\right) \mathrm{L}-1$ and $300 \mathrm{~min}$ ozone exposure-time, they obtained greater reductions in levels of fungal count total, DON and aflatoxins in wheat. Our experiments reported that peanut seeds reduce fungus was more significant in smaller layers of grain column and in longer exposure times [29].

The results for the percentage of fungus reduction in sunn hemp seeds can be attributed to high oxidative potential ozone gas. The inactivation or growth inhibition of microorganism by ozone gas is due to oxidation of the components of the cell wall and membrane, as well as on mobile content elements, such as enzymes and nucleic acids. $[30,31]$.

As seen, the variable that most influenced fungal count reductions was ozone exposure time followed by the column height. This is due to the reactive nature of the ozone that moves slowly through the grain layer [32]. There are also, two distinct phases movement to the ozone, first: the ozone concentration decreases as it moves vertically through the grain due to the oxidation reaction with organic material on the surface of the grain. The second phase corresponds to free movement of ozone when these reactive sites are eliminated [33].

As it was possible to observe the results of electrical conductivity were not influenced by exposure to ozone and also showed higher values of electrical conductivity for both treatments and control. According to [34] normal values of conductivity of Sunn hemp seeds ranged from to $0 \mu \mathrm{S} \mathrm{cm} \mathrm{g} \mathrm{g}^{-1}$, lower values compared to the control value of this study of $46 \mu \mathrm{S} \mathrm{cm}^{-1} \mathrm{~g}^{-1}$. Accordingly, such behavior can be explained by the fact that rupture of the membranes, detected electrical conductivity test through the release of exudates, is a natural consequence of seeds, whose intensity varied according to the exposure time of $\left(\mathrm{O}_{3}\right)$ (Fig. 2B).

The absence of effect of ozone on quality was also observed by other authors, as Freitas et al. (2017), in which ozone did not affect the electrical conductivity and the germination of the grains of corn using a concentration of $0.86 \mathrm{mg} \mathrm{O}_{3} \mathrm{~L}-1$ at periods 10$60 \mathrm{~min}$ of exposure to ozone. The results were also similar to those found in the literature in which ozone did not affect the quality of peanut [36], carrots [37] and black mulberry [38]. Also, our previous report using ozone into air drying confirmed the efficiency of ozonation on wheat seeds without damaging your physiologic quality [26]. However, the effects of ozone on physiological properties depend on the ozone dose applied and the integrity of the grain affected by fungal infection.

For the moisture content explains that due to the hygroscopic properties of seeds of sunn hemp water loss may have occurred due to natural air injection used in conjunction with ozone gas. Thus, the due vapor pressure of water from the air injected to be less than the vapor pressure of the seeds causes the decrease in the moisture content of the seeds, this reduction is influenced also by the exposure time of ozone. Others authors $[36,39]$ also obtained lowering of grain moisture content during the ozonation process.

Therefore, as it was possible to observe ozonation can be considered a highly effective fungal decontamination method in grain and seeds without prejudice to physiological status and ensure maintenance of quality during postharvest. However, other factors should be considered and evaluated to better understand the processes of ozonation, such as grain mass temperature, ozone concentration, and water content, and more complex analyses must be made, such as physic-chemical and enzymes, to improve the ozonation in agricultural products. 


\section{CONCLUSIONS}

Experiment in CCRD shows different fungi count reductions in seed samples of sunn hemp ozonized. The results of this study suggest that the largest fungal reduction is obtained using $102.3 \mathrm{~min}$ ozone exposure and height $10 \mathrm{~cm}$ layer. The results also show that ozone did not influence the quality of the seeds. Thus, ozonation can be considered an effective method for decontamination of seeds and maintain your quality. Considering that, it can be useful in the improvement of industrial processes and as an efficient method of grain and seed conservation without accumulation of chemical waste.

\section{REFERENCES}

[1] Wang, K., Sipes B.S,. Schmitt D.P. 2002. Crotalaria As a Cover Crop for Nematode Management : a Review. Nematropic, 32(4584), 35-57.

[2] Hassanali, A., Herren H., Khan Z.R., Pickett J.A., Woodcock C.M. 2008. Integrated pest management: the push-pull approach for controlling insect pests and weeds of cereals, and its potential for other agricultural systems including animal husbandry. Philosophical Transactions of the Royal Society B: Biological Sciences, 363(1491), 611-621.

[3] Pickett, J.A., Woodcock C.M., Midega C.A.O., Khan Z.R.. 2014. Push-pull farming systems. Current Opinion in Biotechnology, 26, 125-132.

[4] Perin, A., Santos R.H.S., Urquiaga S.S., Cecon P.R., Guerra J.G.M., Freitas G.B. 2006. Sunnhemp and millet as green manure for tropical maize production. Scientia Agricola, 63(5), 453-459.

[5] Tang, Y., Li X., Zhang B., Chen P.X., Liu R., Tsao R.. 2015. Characterisation of phenolics, betanins and antioxidant activities in seeds of three Chenopodium quinoa Willd. genotypes Food Chemistry, 166, 380-388.

[6] Giordano, B.N., Simao V., Manfio D., Galvao S., Scussel J.N., V.. Scussel. 2010. Reduction of in-shell Brazil nut (Bertholletia excelsa H.B.K.) aflatoxin contamination by ozone gas application during storage. 10th International Working Conference on Stored Product Protection Reduction, 566-572.

[7] Karaca, H., Walse S.S., Smilanick J.L. 2012. Effect of continuous 0. $\mu \mathrm{L} / \mathrm{L}$ gaseous ozone exposure on fungicide residues on table grape berries. Postharvest Biology and Technology, 64(1), 154-159.

[8] Luo, X., Wang R., Wang L., Li Y., Wang Y., Chen Z. 2014. Detoxification of aflatoxin in corn flour by ozone. Journal of the Science of Food and Agriculture, 94(11), 2253-2258

[9] Raila, A., Lugauskas A., Steponavičius D, Railiene M, Steponavičiene A., Zvicevičius E.. 2006. Application of ozone for reduction of mycological infection in wheat grain. Annals of Agricultural and Environmental Medicine, 13(2), 287-294.

[10] Bhattarai, S., Bottenus D., Ivory C.F., Gao A.H., Bule M., Garcia-Perez M., Chen S.. 2015. Simulation of the ozone pretreatment of wheat straw. Bioresource Technology, 196,78-87.

[11] Sahab, A.F., Hassanien F.R., El-nemr S.E., Abdel-alim H.A., Mosaad A.. 2013. Effect of Ozone Gaseous On Aflatoxin Degradation And Fat And Protein Content In Peanut seeds, Journal of Applied Sciences Research, 9(3), 2170-2175.

[12] MAPA (2003) Ministry of Agriculture, Livestock and Food Supply of Brazil. Normative Instruction No. 6 . Brasília-Brazil

[13] Samson R a., Houbraken J, Thrane U, et al. (2010) Food and Indoor Fungi.

[14] Nakagawa, J. 1999. Testes de vigor baseados no desempenho de plântulas. In J. B. Krzyzanowski, F.C.; Vieira, R.D.; França Neto, ed. Vigor de sementes: conceitos e testes. Londrina: Abrates, 1-24. 
[15] MAPA (2009) Ministry of Agriculture, Livestock and Food Supply of Brazil. Rules for seed analysis.Normative Instruction. Brasília-Brazil.

[16] Inan, F., M. Pala, and I. Doymaz. 2007. Use of ozone in detoxification of aflatoxin B1 in red pepper. Journal of Stored Products Research, 43(4), 425-429.

[17] Torlak E., Akata I., Erci F., Uncu A.T. 2016. Use of gaseous ozone to reduce aflatoxin B1 and microorganisms in poultry feed. Journal of Stored Products Research, 68, 44-49

[18] Yeoh W.K., Ali A., Forney C.F. 2014. Effects of ozone on major antioxidants and microbial populations of fresh-cut papaya. Postharvest Biology and Technology,89, 56-58.

[19] Öztekin S., Zorlugenç B., Zorlugenç F.K. 2006. Effects of ozone treatment on microflora of dried figs. Journal of Food Engineering 75(3), 396-399.

[20] Habibi Najafi M.B., Haddad Khodaparast M.H. 2009. Efficacy of ozone to reduce microbial populations in date fruits. Food Control, 20(1), 27-30.

[21] Isikber A.A., Athanassiou C.G. 2015. The use of ozone gas for the control of insects and micro-organisms in stored products. Journal of Stored Products Research, 64, 139-145.

[22] Hansen L.S., Hansen P., Vagn Jensen K.M. 2013. Effect of gaseous ozone for control of stored product pests at low and high temperature. J. of Stored Products Research 54, 59-63.

[23] Concha-Meyer A, Eifert J.D., Williams R.C., Marcy J.E., Welbaum G.E. Shelf life determination of fresh blueberries (Vaccinium corymbosum) stored under controlled atmosphere and ozone. International Journal of Food Science, 2015.

[24] Savi G.D., Scussel V.M. 2014. Effects of Ozone Gas Exposure on Toxigenic Fungi Species from Fusarium, Aspergillus, and Penicillium Genera. Ozone: Science and Engineering, 36(2), 144-152.

[25] Savi G.D., Piacentini K.C., Scussel V.M. 2015. Reduction in residues of deltamethrin and fenitrothion on stored wheat grains by ozone gas. J.of Stored Products Research, 61, 65-69.

[26] Granella SJ, Christ D, Werncke I, Bechlin T.R Machado Coelho, S.R. 2018.Effect of drying and ozonation process on naturally contaminated wheat seeds. Journal of Cereal Science, 80, 205-211.

[27] Aboltins A., Palabinskis J., Lauva A. 2010. Grain active ventilation using ozonized air. Acta Horticulturae, 858, 449-456.

[28] Trombete F.M., Porto Y.D., Freitas-Silva O., Pereira R.V., Direito G.M., Saldanha T., Fraga M.E.. 2017. Efficacy of Ozone Treatment on Mycotoxins and Fungal Reduction in Artificially Contaminated Soft Wheat Grains. Journal of Food Processing and Preservation, 41(3), 1-10

[29] Ortega Sanchez B.A., Alencar E.R., Oliveira Pineli L.L., Souza Ferreira W.F., Almeida Roberto M. 2016. Tracing interactions among column height, exposure time and gas concentration to dimension peanut antifungal ozonation. LWT - Food Science and Technology, 65, 668-675.

[30] Cullen P.J., Tiwari B.K., O’ onnell C.P., Muthukumarappan K. 2009. Modelling approaches to ozone processing of liquid foods. Trends in Food Science and Tech., 20(3-4), 125-136.

[31] Pascual A., Llorca I., Canut A. 2007. Use of ozone in food industries for reducing the environmental impact of cleaning and disinfection activities. Trends in Food Science and Technology, 18(SUPPL. 1).

[32] Mendez F., Maier D., Mason L., Woloshuk C. 2003. Penetration of ozone into columns of stored grains and effects on chemical composition and processing performance. Journal of Stored Products Research, 39(1), 33-44.

[33] Kells S.A., Mason L.J., Maier D.E., Woloshuk C.P. 2001. Efficacy and fumigation characteristics of ozone in stored maize. J. of Stored Products Research, 37(4), 371-382.

[34] Silva A.B.C., Galvão Í.M., Barbosa R.M., Silva C.B., Vieira R.D. 2015. Controlled deterioration test for evaluation of sunn hemp seed vigor. J. of Seed Science, 37, 249-253.

[35] Freitas R.S., Faroni L.R.D., Queiroz M.E.L.R., Heleno F.F., Prates L.H.F. 2017. Degradation kinetics of pirimiphos-methyl residues in maize grains exposed to ozone gas. Journal of Stored Products Research, 74, 1-5. 
[36] Alencar E.R., Faroni L.R.D., Soares N.F.F., Carvalho M.C.S., Pereira K.F. 2011. Effect of the ozonization process on the quality of peanuts and crude oil. Revista Brasileira de Engenharia Agrícola e Ambiental, 15(2), 154-160.

[37] Souza L.P., Faroni L.R.D.A., Heleno F.F., Cecon P.R., Gonçalves T. .C. , Silva G.J., Prates L.H.F. 2018. Effects of ozone treatment on postharvest carrot quality. LWT - Food Science and Technology, 90, 53-60.

[38] Tabakoglu N., Karaca H. 2018. Effects of ozone-enriched storage atmosphere on postharvest quality of black mulberry fruits (Morus nigra L.). LWT, 92, 276-281.

[39] Ozkan R., Smilanick J.L., Karabulut O.A. 2011. Toxicity of ozone gas to conidia of Penicillium digitatum, Penicillium italicum, and Botrytis cinerea and control of gray mold on table grapes. Postharvest Biology and Technology, 60(1), 47-51.

\section{UTICAJ PENETRACIJE OZONA NA KVALITET UZORKA SEMENA KONOPLJE (Crotalaria spectabilis Roth)}

\section{Suian José Granella ${ }^{1}$, Taise Raquel Bechlin ${ }^{1}$, Ivan Werncke ${ }^{1}$, Divair Christ ${ }^{1}$ \\ ${ }^{1}$ Western Parana State University, Exact Sciences \& Technology Center, Pgeagri, Cascavel-PR, Brasil}

Sažetak: Ozon poseduje visok oksidativni potencijal širokog mikrobiološkog spektra i može se upotrebiti direktno u procesu zaštite zrna i semena za dekontaminaciju gljivica i redukciju mikotoksina. Cilj ovog rada bio je da proceni uticaj ozonacije u kontrolu gljivica na kvalitet semena konoplje. Za to je koriš e na cilindrična posuda PVC-a debljine $5 \mathrm{~cm}$ za ozoniranje na različitim visinama sloja semena od 2,95 do $7,05 \mathrm{~cm}$ sa različitim vremenskim trajanjem dejstva ozona $(17,7 ; 30 ; 60 ; 90$ i 0 , min) prema centralnom kompozitnom rotiraju e m disku (CCRD).

Procenjen je uticaj ozona na dekontaminaciju zrna od gljivica kod sadržaja vlage $i$ električne provodljivosti semena za seme konoplje. Rezultati CCR pokazuju različite vrednosti smanjenja broja gljivica kao linearni model drugog reda (prosečno apsolutno odstupanje je $7,79 \%$ i $\left.\mathrm{R}^{2}=0,67\right)$. Smanjenje broja gljivica $(9,7 \%)$ je znatno ve e u nižim slojevima cilindrične posude sa uzorkom semena i dužim vremenskim intervalima dejstva ozona, vrednosti koje odgovaraju $10 \mathrm{~cm}$ i 102,7 min, respektivno.

Rezultati istraživanja su takođe pokazali da process ozoniranja nije značajno uticao na električnu provodljivost i sadržaj vlage u uzorku semena konoplje (p-vriednost $0,05)$. Na taj način primena ozona može osigurati održavanje semena konoplje nakon žetve bez ošte e nja kvaliteta zrna.

Ključne reči: Ozonizacija, Crotalaria spectabilis Roth, gljivice, post-harvest kvalitet

Prijavljen:

Submitted:

Ispravljen:

Revised:

01.10 .2018

Prihva en:

Accepted:

10.10 .2018 